Research Article

\title{
Latrine Availability and Associated Factors among Religious Institutions in Northern Ethiopia, 2018
}

\author{
Mulugeta Woldu Abrha (D), Kiros Demoz Ghebremedhin, \\ and Tesfay Teklemariam Weldeslasie
}

\author{
Tigray Health Research Institute, Mekelle, Ethiopia \\ Correspondence should be addressed to Mulugeta Woldu Abrha; mulugetawoldu425@gmail.com
}

Received 4 December 2019; Revised 26 August 2020; Accepted 8 October 2020; Published 28 October 2020

Academic Editor: Pam R. Factor Litvak

Copyright (C) 2020 Mulugeta Woldu Abrha et al. This is an open access article distributed under the Creative Commons Attribution License, which permits unrestricted use, distribution, and reproduction in any medium, provided the original work is properly cited.

\begin{abstract}
Background. Religious institutions found in the community not only uphold belief and cultural values but can also act as a force for positive change and development. Improved sanitation and hygiene are crucial in these institutions to decrease preventable infections due to unsanitary conditions. However, there are no studies among religious institutions on availability of latrines. Therefore, this study was conducted to assess latrine availability and associated factors among religious institutions in the Tigray Region, Ethiopia. Method. An institution-based cross-sectional study design was conducted in the Tigray Region, Northern Ethiopia. Multistage sampling was used to sample 385 religious institutions. Data were collected using a pretested, structured questionnaire and observation checklist. Logistic regression was fitted, and an odds ratio with $95 \%$ confidence interval (CI) with $p$ value less than 0.05 was used to determine the predictors of latrine availability. Analysis was carried out using the SPSS $20^{\mathrm{TM}}$ software package. Results. In this study, latrine availability was $32.8 \%$. It was significantly affected by currently saved money towards having a latrine (adjusted odds ratio (AOR): $0.32,95 \%$ confidence interval (CI) $[0.25,0.42]$ ), any messages seen, heard, or received on sanitation and hygiene (AOR: $0.43,95 \%$ CI $[0.38,0.51]$ ), and the place where messages were seen, heard, or received (AOR: 2.95, 95\% CI $[1.11,5.55])$. Conclusion. Latrine availability was very low when compared to the national target of $100 \%$ among religious institutions and was affected by the currently saved money towards having a latrine, any messages seen, heard, or received on sanitation and hygiene, and the place where the messages were received. Information regarding latrine availability should be provided to the community visiting religious institutions through available channels and promotion of practical models.
\end{abstract}

\section{Background}

Lack of sanitation is a serious health risk, affecting billions of people around the world, particularly the poor and disadvantaged. It also contributes to stunting and impaired cognitive function and impacts on well-being through school attendance, anxiety, and safety with lifelong consequences, especially for women and girls $[1,2]$. Lack of sanitation facilities compels people to practice open defecation, which increases the risk of disease transmission and perpetuates a vicious cycle of disease and poverty. The countries where open defection is most widespread have the highest number of deaths of children aged under 5 years as well as the highest levels of malnutrition and poverty and big disparities of wealth [3]. The disease burden associated with poor water, sanitation, and hygiene is estimated to account for $4.0 \%$ of all deaths and $5.7 \%$ of the total disease burden in disability-adjusted life year (DALY) worldwide, principally through diarrheal diseases, schistosomiasis, trachoma, ascariasis, trichuriasis, and hookworm infection [4]. About 1.8 million people die every year due to diarrheal diseases, and children under the age of 5 account for $90 \%$ of diarrheal deaths. Moreover, $88 \%$ of diarrheal diseases are attributed to unsafe water supply, inadequate sanitation, and poor hygiene [5].

In Ethiopia, up to $60 \%$ of the current disease burden is attributable to poor sanitation, where $15 \%$ of total deaths are from diarrhea, mainly among the large population of 
children under five years. Children in the country still suffer from diarrheal diseases, respiratory problems, and malnutrition. According to Ethiopian demographic and health survey, the two-week prevalence of diarrheal diseases was $12 \%$ among children under five years of age $[6,7]$.

The local religious institutions are often found at the heart of a community, not only upholding belief, cultural values, and social tradition, but also as a force for positive change and development. Holy springs are frequently contaminated with fecal bacteria, and different infections are potentially transmitted from an infected person to a healthy one by various routes involving excreta [7]. A study from India showed that a possible source of infection for a confirmed case of cholera in a 3-day-old neonate was by holy water given to the baby [8]. Thus, religious institutions might be a point of infection for the community served there, and despite concerted efforts by governmental and nongovernmental organizations, water and adequate sanitation still remain a challenge for these institutions. The study was conducted to determine latrine availability and associated factors among religious institutions in the Tigray Region, Ethiopia, aiming to establish baseline information. This will be very important for local decision makers in order to obtain an overview of the current status and what should be done in the future.

\section{Methods}

2.1. Study Design, Setting, and Participants. A cross-sectional, religious institution-based study design was carried out from May to June 2018 in the Tigray Region, Northern Ethiopia, $780 \mathrm{~km}$ far from the capital city Addis Ababa. Population source was all religious institutions found in the Tigray Region, while the study populations were those religious institutions found in the selected district.

2.2. Sampling Technique and Procedure. Multistage probability sampling of four stages was used to select religious institutions. Using simple random sampling technique, three zones were selected from the seven zones of the Tigray Region, and ten districts were sampled from the selected zones. Then, all the religious institutions found in each district were first listed, and the eligible institutions were included. Thereafter, religious institutions were questioned consecutively till fulfillment of the sample size, which was determined using single population formula with prevalence estimates of $50 \%$ and a marginal error of $0.05 \%$ at $95 \%$ confidence level. The total sample size was 385 . Respondents were the heads or delegates of the religious institution, yet in situations where the head or delegate was not available after two or three visits, others in a similar position were questioned, and these were selected purposely.

\subsection{Data Collection Instrument and Quality Management.}

The data were collected using face-to-face interviews with the heads of the institutions and observation. One week prior to the actual data collection period, a pretest was done, and based on the findings, minor modifications of questions, wordings, and phrases were made. During the data collection time, a clear introduction explaining the purpose and objectives of the study was provided to respondents. Close supervision, honest communication, and on-spot decisions were done during data collection.

2.4. Explanatory Variables. The study variables were selected after reviewing relevant literature $[4,7,8]$, according to the objective of the research and considering the local context of the study area. The dependent variable was latrine availability. The independent variables were general characteristics, communication, and behavioral and environmental factors.

2.5. Operational Definition. Religious institution: formal institutions which have permanent administration including Christian churches, Muslim mosques, and Catholic churches.

Pretest: pretesting is the stage in survey research when survey questions and questionnaires are tested on members of target population/study population to evaluate the reliability and validity of the survey instruments prior to their final distribution.

Diseased in this institution: this means whether there were any illnesses like diarrhea, related to the environmental sanitation.

2.6. Statistical Analyses. Data were coded and entered into EPi-Info version 7 software and analyzed using SPSS version 20. Frequency distribution tables, graphs, and narratives were used to present the findings. Frequency distributions, percentages, and odds ratios (ORs) with 95\% confidence level (C.I) were calculated for statistical significance tests between variables, and a logistic regression model was used to identify predictors of latrine availability of religious institutions.

2.7. Ethical Consideration. Ethical approval and clearance were obtained from the Tigray Health Research Institution, and official letters were obtained from religious leaders. Written informed consent was warranted from all participants.

\section{Results}

3.1. Characteristics of the Religious Institutions. In the present study, a total of 385 religious institutions were sampled and 351 of them were included in the study. Of these, 285 (81.2\%) were Orthodox churches. Majority of the religious institutions (288(82\%)) were church/mosque and $54 \%$ of them $(n=188)$ were found in rural areas. The mean age of the institution was 83.2 years with \pm SD of \pm 119 . The mean age of persons permanently living in the institutions was $11.6 \pm 36.65$, as members of monasteries and also sometimes students (Table 1). 
TABLe 1: General characteristics of religious institutions, Northern Ethiopia, $2017(n=351)$.

\begin{tabular}{|c|c|c|c|}
\hline Characteristics & Category & Frequency & Percentage \\
\hline \multirow{4}{*}{ Type of religious institution } & Orthodox church & 285 & 81.2 \\
\hline & Muslim mosque & 60 & 17.1 \\
\hline & Catholic church & 4 & 1.1 \\
\hline & Protestant church & 2 & 0.6 \\
\hline \multirow{2}{*}{ Service given in the institution } & Church/mosque only & 288 & 82.1 \\
\hline & Church with holy water & 63 & 17.9 \\
\hline \multirow{2}{*}{ Residence } & Urban & 159 & 45.8 \\
\hline & Rural & 188 & 54.2 \\
\hline Characteristics & & & \\
\hline Age of the institution & & & \\
\hline Age of the respondent & & & \\
\hline People permanently living here & & & \\
\hline Estimation of the community served here & & & \\
\hline
\end{tabular}

3.2. Environmental Characteristics. Of the institutions, 236 $(67.2 \%)$ had no latrines. When available, the majority were pit latrines $(80,69.6 \%)$. For $57 \%$ of the institutions, the reasons for not having latrine were that the cost for building one was too high or neither materials nor external assistance was available. In around $98 \%$ of the $(n=233)$ institutions without latrine, the priests and servants defecate openly. At the time of data collection, $82(23.4 \%)$ latrines were functional. Approximately one-third or 41 (35.7\%) of the latrines were less than $15 \mathrm{~m}$ from the drinking water/holy water. Seventy-six percent of the latrines were at a distance of above $12 \mathrm{~m}$ from the room priests serve (Table 2).

3.3. Behavioral Characteristics. Regarding the behavioral condition, the majority $(319,90.9 \%)$ of the respondents believed that using latrine can prevent disease, and 9 out of 10 respondents believed that hand washing can prevent diseases. Of the religious institutions that have hand washing facilities with a latrine, $32(82.1 \%)$ used only water for hand washing. Fifty-six percent $(n=22)$ of the community or priests serving in the institutions wash their hands after using toilet. Half $(n=59,51.3 \%)$ of the respondents who have latrine maintained their latrine properly (Table 3 ).

3.4. Communication-Related Factors. Seventy-eight percent $(n=275)$ of the respondents had seen, heard, or received any messages or materials on sanitation and hygiene. Around one-third of 90 respondents had received messages on building latrine. One hundred twenty five (45.5\%) of the respondents heard or observed the messages from community meetings. Three out of ten $(n=103,29.3 \%)$ of the sanitation and hygiene messages were delivered by health extension workers. Less than half of 153 (43.6\%) respondents prefer radio or/and television for health education (Table 4).

3.5. Factors Associated with the Availability of Latrine. To identify significant variables that were associated with the outcome variable, all significant variables with $p$ value $<0.25$ in bivariable analysis were fitted into the final model.
Currently, any money saved towards having a latrine (AOR: $0.32,95 \%$ CI $[0.25,0.42])$, seen, heard, or received any messages on sanitation and hygiene (AOR: 0.43, 95\% CI $[0.38,0.51])$, and place where these messages had been seen, heard, or received (AOR: 2.95, 95\% CI [1.11, 5.55] were the independent factors of availability of latrine.

Religious institutions that had not saved money for sanitation and hygiene were $68 \%$ times less likely to have latrine than institutions that had saved money. The heads of religious institutions that had not seen, heard, or received any messages on sanitation and hygiene were $57 \%$ times less likely to have latrine than those who had. The heads of religious institutions that had received messages from posters or leaflets and newspapers or magazines were 2.95 times more likely to own latrine than those having received messages by television and/or radio (Table 5).

\section{Discussion}

The main objective of this study was to assess the level of latrine availability and its associated factors in religious institutions in the Tigray Region. Accordingly, the present study revealed that the overall availability of latrine was $32.8 \%$. The national and regional target for latrine availability is $100 \%$ in all settings [9]. However, the study reported that only three out of ten religious institutions had a latrine, implying that there is very low sanitary coverage among religious institutions in the region. This result was low compared with a previous study reporting that 59\% of households in Ethiopia own a latrine [10] and the 2016 Ethiopian Demographic Health Service which showed that $56 \%$ of rural households use unimproved toilet facilities [11]. This might be due to the fact that there were no persistent health education programs carried out to visitors of religious institutions. Consequently, communities who are served there will not perceive that building latrines can prevent from different diseases and childhood diarrhea. Another possible reason could be that heads of the institution did not handle visitors' defecation practice strongly enough.

This study exposed that religious institutions that had saved money for sanitation and hygiene were significantly 
TABle 2: Environmental conditions of religious institutions, Northern Ethiopia, $2017(n=351)$.

\begin{tabular}{|c|c|c|c|}
\hline Characteristics & Category & Frequency & Percentage \\
\hline \multirow{2}{*}{ Any type of latrine } & Yes & 115 & 32.8 \\
\hline & No & 236 & 67.2 \\
\hline \multirow{2}{*}{ Type of latrine } & Pit latrine & 80 & 69.6 \\
\hline & Others & 35 & 30.4 \\
\hline \multirow{3}{*}{ Reasons for not having latrine } & $\begin{array}{c}\text { Cost is too high, no materials, and no external } \\
\text { assistance }\end{array}$ & 202 & 85.47 \\
\hline & Open defecation tradition and habit & 19 & 8.12 \\
\hline & Not thought about it and no one to build latrine & 15 & 6.41 \\
\hline \multirow{2}{*}{ Place of defecation } & Open field & 233 & 98.7 \\
\hline & Other & 3 & 1.3 \\
\hline \multirow{2}{*}{ Functional latrine } & Yes & 82 & 71.30 \\
\hline & No & 33 & 28.70 \\
\hline \multirow{3}{*}{$\begin{array}{l}\text { Distance of latrine to the closest drinking water/holy } \\
\text { water }\end{array}$} & Below 15 meters & 41 & 35.7 \\
\hline & 15-30 meters & 25 & 21.7 \\
\hline & Greater than 30 meters & 49 & 42.6 \\
\hline \multirow{3}{*}{ Distance of latrine from the room priests serve } & Below 6 meters & 18 & 15.7 \\
\hline & 6-12 meters & 9 & 7.8 \\
\hline & Above 12 meters & 88 & 76.5 \\
\hline \multirow{3}{*}{ Number of rooms of the latrine } & Below 2 rooms & 59 & 51.3 \\
\hline & 2-4 rooms & 29 & 25.2 \\
\hline & Above 4 rooms & 24 & 23.5 \\
\hline \multirow{2}{*}{ Clean latrine } & Yes & 55 & 47.8 \\
\hline & No & 60 & 52.2 \\
\hline \multirow{3}{*}{ Frequency of cleaning latrine } & Daily & 42 & 36.5 \\
\hline & Weekly & 35 & 30.4 \\
\hline & Almost never & 38 & 33.0 \\
\hline \multirow{2}{*}{ Presence of hand washing } & Yes & 39 & 33.9 \\
\hline & No & 76 & 66.1 \\
\hline \multirow{2}{*}{ Type of hand washing } & Tap only and sink & 18 & 46.2 \\
\hline & Water pot/container and cup & 21 & 53.8 \\
\hline \multirow{2}{*}{ Latrine condition } & Need maintenance & 80 & 69.6 \\
\hline & No need of maintenance & 35 & 30.4 \\
\hline \multirow{2}{*}{ Reasons for not improving/changing latrine type } & Financial problem/no support & 40 & 50.0 \\
\hline & Personal and space problem & 40 & 50.0 \\
\hline \multirow[b]{2}{*}{ Possible ways encouraging you to build a latrine } & Full subsidy and contribution from NGOs & 147 & 62.3 \\
\hline & $\begin{array}{l}\text { Community pressure and/or material and labor } \\
\text { assistance }\end{array}$ & 89 & 37.7 \\
\hline \multirow{2}{*}{ Anyone diseased in this institution } & Yes & 42 & 12.0 \\
\hline & No & 309 & 88.0 \\
\hline \multirow{2}{*}{ Currently any money saved towards having a latrine } & Yes & 16 & 6.8 \\
\hline & No & 220 & 93.2 \\
\hline \multirow{2}{*}{ Institution discussed about building latrine } & Yes & 113 & 47.9 \\
\hline & No & 123 & 52.1 \\
\hline
\end{tabular}

TABLE 3: Behavioral conditions of religious institutions, Northern Ethiopia, 2017.

\begin{tabular}{|c|c|c|c|}
\hline Characteristics & Category & Frequency & Percentage \\
\hline \multirow{2}{*}{ Do you believe that using latrine can prevent disease? } & Yes & 319 & 90.9 \\
\hline & No & 32 & 9.1 \\
\hline \multirow{2}{*}{ Do you believe that hand washing can prevent disease? } & Yes & 320 & 91.2 \\
\hline & No & 31 & 8.8 \\
\hline \multirow{2}{*}{ Materials used in hand washing } & Only water & 32 & 82.1 \\
\hline & Water + soap or ash & 7 & 17.9 \\
\hline \multirow{2}{*}{ Wash their hands after using toilet (community and priests) } & Yes & 22 & 56.4 \\
\hline & No & 17 & 43.6 \\
\hline \multirow{2}{*}{ Maintaining the latrine properly } & Yes & 59 & 51.3 \\
\hline & No & 56 & 48.7 \\
\hline
\end{tabular}


TABLe 4: Communication-related factors of religious institutions, Northern Ethiopia, 2017.

\begin{tabular}{|c|c|c|c|}
\hline Characteristics & Category & Frequency & Percentage \\
\hline \multirow{2}{*}{$\begin{array}{l}\text { Seen, heard, or received any messages or materials on sanitation } \\
\text { and hygiene }\end{array}$} & Yes & 275 & 78.3 \\
\hline & No & 76 & 21.7 \\
\hline \multirow{5}{*}{$\begin{array}{l}\text { Kinds of sanitation and hygiene messages you have seen, heard, or } \\
\text { received }\end{array}$} & Build a latrine & 90 & 32.8 \\
\hline & Use a latrine/stop open defecation & 58 & 21.2 \\
\hline & Proper solid and liquid waste management & 15 & 5.5 \\
\hline & Wash hands with soap & 65 & 23.7 \\
\hline & Water and food hygiene & 46 & 16.8 \\
\hline \multirow{4}{*}{ Where did you see, hear, or receive these messages } & $\begin{array}{l}\text { Posters or leaflets and newspapers or } \\
\text { magazines }\end{array}$ & 55 & 20.0 \\
\hline & At community meetings & 125 & 45.5 \\
\hline & When visiting a health facility & 56 & 20.4 \\
\hline & On television and/or radio & 39 & 14.2 \\
\hline \multirow{5}{*}{ From whom did you hear/receive these messages } & Village chief & 82 & 29.8 \\
\hline & Commune chief/council & 29 & 10.5 \\
\hline & $\begin{array}{c}\text { Government agency other than health } \\
\text { department }\end{array}$ & 35 & 12.7 \\
\hline & From health extension workers & 103 & 29.3 \\
\hline & From coordinators of church & 26 & 7.4 \\
\hline \multirow{4}{*}{$\begin{array}{l}\text { Preferred channel of communication or mechanisms to get } \\
\text { information }\end{array}$} & Radio or/and TV & 153 & 43.6 \\
\hline & House visit & 90 & 25.6 \\
\hline & Through church/mosque & 63 & 17.9 \\
\hline & Pictures/posters & 45 & 12.8 \\
\hline
\end{tabular}

TAвLE 5: The main predictors of latrine availability among religious institutions of Tigray Region, Northern Ethiopia, 2018 ( $n=351$ ).

\begin{tabular}{|c|c|c|c|c|}
\hline \multirow{2}{*}{ Characteristics } & \multicolumn{2}{|c|}{ Latrine availability, $n(\%)$} & \multicolumn{2}{|c|}{ OR $(95 \% \mathrm{CI})$} \\
\hline & Yes & No & Crude & Adjusted \\
\hline $\begin{array}{l}\text { Possible ways encouraging you to build a latrine } \\
\text { Full subsidy and contribution from NGOs } \\
\text { Community pressure and/or material and labor assistance }\end{array}$ & $\begin{array}{l}12(8.16) \\
10(11.24) \\
\end{array}$ & $\begin{array}{l}135(91.84) \\
79(88.76) \\
\end{array}$ & $\begin{array}{c}1.42(0.58-3.45) \\
1 \\
\end{array}$ & NS \\
\hline $\begin{array}{l}\text { Currently any money saved towards having a latrine } \\
\text { Yes } \\
\text { No }\end{array}$ & $\begin{array}{c}9(56.25) \\
57(25.91) \\
\end{array}$ & $\begin{array}{c}7(43.75) \\
163(74.09) \\
\end{array}$ & $\begin{array}{c}1 \\
0.27(0.09-0.76) \\
\end{array}$ & $\begin{array}{c}1 \\
0.32(0.25-0.42) \\
\end{array}$ \\
\hline $\begin{array}{l}\text { Institution discussed about building latrine } \\
\text { Yes } \\
\text { No }\end{array}$ & $\begin{array}{l}34(30.09) \\
30(24.39) \\
\end{array}$ & $\begin{array}{l}79(69.91) \\
93(75.61) \\
\end{array}$ & $\begin{array}{c}1 \\
0.75(0.42-1.33) \\
\end{array}$ & NS \\
\hline $\begin{array}{l}\text { Seen, heard, or received any messages or materials on san } \\
\text { Yes } \\
\text { No }\end{array}$ & $\begin{array}{l}n \text { and hygier } \\
105(38.18) \\
10(13.16)\end{array}$ & $\begin{array}{c}170(61.82) \\
66(86.84)\end{array}$ & $\begin{array}{c}1 \\
0.25(0.12-0.49)\end{array}$ & $\begin{array}{c}1 \\
0.43(0.38-0.51)\end{array}$ \\
\hline $\begin{array}{l}\text { Kinds of sanitation and hygiene messages you have seen, he } \\
\text { Build a latrine } \\
\text { Use a latrine/stop open defecation } \\
\text { Proper solid and liquid waste management } \\
\text { Wash hands with soap } \\
\text { Water and food hygiene }\end{array}$ & $\begin{array}{l}\text { or received } \\
26(28.89) \\
27(46.55) \\
8(53.33) \\
24(36.92) \\
20(43.48) \\
\end{array}$ & $\begin{array}{l}64(71.11) \\
31(53.45) \\
7(46.67) \\
41(63.08) \\
26(56.52) \\
\end{array}$ & $\begin{array}{l}1.89(0.90-3.97) \\
0.88(0.41-1.92) \\
0.67(0.21-2.17) \\
1.31(0.61-2.84) \\
1\end{array}$ & NS \\
\hline $\begin{array}{l}\text { Where did you see, hear, and receive these messages } \\
\text { Posters or leaflets and newspapers or magazines } \\
\text { At community meetings } \\
\text { When visiting a health facility } \\
\text { On television and/or radio }\end{array}$ & $\begin{array}{l}17(30.91) \\
48(38.40) \\
14(25.00) \\
20(51.28) \\
\end{array}$ & $\begin{array}{l}38(69.09) \\
77(61.60) \\
42(75.00) \\
19(48.72) \\
\end{array}$ & $\begin{array}{l}2.35(1.01-5.50) \\
1.69(0.82-3.48) \\
3.16(1.32-7.55) \\
1\end{array}$ & $\begin{array}{l}2.95(1.11-5.55) \\
1.95(0.86-3.58) \\
3.01(1.31-6.55) \\
1\end{array}$ \\
\hline $\begin{array}{l}\text { From whom did you hear/receive these messages } \\
\text { Village chief } \\
\text { Commune chief/council } \\
\text { Government agency other than health department } \\
\text { From health extension workers } \\
\text { From coordinators of church }\end{array}$ & $\begin{array}{l}23(28.05) \\
13(44.83) \\
16(45.71) \\
39(37.86) \\
14(53.85) \\
\end{array}$ & $\begin{array}{l}59(71.95) \\
16(55.17) \\
19(54.29) \\
64(62.14) \\
12(46.15) \\
\end{array}$ & $\begin{array}{l}2.99(1.21-7.43) \\
1.44(0.49-4.16) \\
1.39(0.50-3.84) \\
1.92(0.80-4.56) \\
1\end{array}$ & NS \\
\hline $\begin{array}{l}\text { Age of the institution } \\
\text { Age of the respondent } \\
\text { People permanently living here }\end{array}$ & & & $\begin{array}{c}1.00(1.0-1) \\
1.014(0.99-1.03) \\
0.99(0.99-1.00)\end{array}$ & $\begin{array}{l}\text { NS } \\
\text { NS } \\
\text { NS }\end{array}$ \\
\hline
\end{tabular}

NS indicates nonsignificance. 
associated with availability of latrine. This is consistent with a study carried out by the World Bank [12], which indicates that "those without latrines tend to be poorer than those higher on the sanitation ladder and open defecators cite "lack of finances" or "do not have money" as key barriers to building latrines or making improvements." Thus, religious institutions that have saved money for the purpose of latrine construction might employ daily laborers to construct the latrine. A study indicated that latrine promotion programs like community-led total sanitation and hygiene were least effective in communities where subsidies had already been given to the community members, meaning that they became reluctant and already expected to get gifts [13]. Thus, institutions having saved money for the purpose of latrine construction might own or build one.

Heads of religious institutions that had not seen, heard, or received any messages on sanitation and hygiene were $57 \%$ times less likely to own latrine than those who had, likely because the latter were better informed about the importance of building latrine facilities and its utilization through health-promotion programs and community mobilization. If communities visiting religious institutions get information about basic sanitation, they might perceive the risk of practicing open defecation, which has the potential to stimulate and shape communities' behaviors [14].

Religious institutions having received information from posters or leaflets and newspapers or magazines were more likely to own latrine than those which received messages by television and/or radio. According to this socioeconomic feature of the community, governmental and nongovernmental community education programs should utilize lowcost mechanism of transmissions. Generally, to increase latrine availability, health professionals should sustainably educate on the implementation of the community-led total sanitation and hygiene approach [15].

\section{Conclusion}

The availability of latrine was very low when compared to the national target of $100 \%$ among religious institutions, and over half of the available latrines required maintenance. Latrine availability was influenced by the currently saved money towards having this basic sanitation facility, any messages on sanitation and hygiene received, and the place where the message had been received. Information regarding latrine availability should be provided to the community visiting religious institutions through available channels and practical model promotion. Messages focusing on proper disposal of human feces should be scaled up throughout the community. Providing enough information about latrine construction and cleanliness through health education is indispensable to improve latrine availability.

\section{Abbreviations}

AOR: Adjusted odds ratio

CI: Confidence interval
DALY: Disability-adjusted life year.

\section{Data Availability}

The datasets used and/or analyzed during the current study are available from the corresponding author on request.

\section{Ethical Approval}

Participation was voluntary. Before the interview, the interviewer explained in detail the content of the questionnaire and informed the participants on confidentiality of their responses and of their free choice to withdraw from the study during the interview or later. Written consent was obtained from all participants. The study was approved by the Institutional Review Board of Tigray Health Research Institute (No: RMT/0061/2018).

\section{Conflicts of Interest}

The authors declare that they have no conflicts of interest.

\section{Acknowledgments}

Special gratitude goes to Tigray Health Research Institute. The authors would like to thank the zone coordinators of the religious institutions for their permission to conduct this research. Finally, the authors would also like to thank the study participants, data collectors, and supervisors. This research was funded by Tigray Health Research Institute.

\section{References}

[1] WHO/sanitation; http://www.who.int/topics/sanitation/en/.

[2] WHO/10 facts on sanitation: http://www.who.int/topics/ sanitation/en/.B.

[3] WHO/10 facts on sanitation: http://www.who.int/features/ factfiles/ sanitation/facts/en/index1.html.C.

[4] A. Prüss, D. Kay, L. Fewtrell, and J. Bartram, "Estimating the burden of disease from water, sanitation, and hygiene at a global level," Environmental Health Perspectives, vol. 110, no. 5, pp. 537-542, 2002.

[5] World Health Organization, "WHO | facts and figures: water, sanitation and hygiene links to health," 2004, http://www. who.int/water_sanitation_health/publications/factsfigures04/ en/.

[6] N. K. Sethi and S. K. Sethi, "Vibrio cholerae diarrhoea in a three-day-old breastfed neonate," The Indian Journal of Pediatrics, vol. 68, no. 8, pp. 791-792, 2001.

[7] F. Greaves, S. Yardley, and E. v. Hoek, The Role of the Church in Improving Access to Sanitation, Loughborough University, England, UK, 2018.

[8] A. K. T. Kirschner, M. Atteneder, A. Schmidhuber, S. Knetsch, A. H. Farnleitner, and R. Sommer, "Holy springs and holy water: underestimated sources of illness?" Journal of Water and Health, vol. 10, no. 3, 2012.

[9] Federal Democratic Republic of Ethiopia, "Ministry of health national hygiene and sanitation strategy for Ethiopia, to enable $100 \%$ adoption of improved hygiene and sanitation," 2005.

[10] W. Awoke and S. Muche, "A cross sectional study: latrine coverage and associated factors among rural communities in 
the district of bahir dar zuria, Ethiopia." BMC Public Health, vol. 13, no. 99, 2013.

[11] Central statistical agency, (CSA) [Ethiopia] and ICF, Ethiopia Demographic And Health Survey 2016, CSA and ICF, Rockville, MD, USA, 2016.

[12] E. Christensen Rand, S. Smets, J. Bevan, and E. Perez, "What influences open defecation and latrine ownership in rural households?" Findings from a Global Review Scaling Up Rural Sanitation, p. 38, 2014.

[13] P. A. Harvey, "Zero subsidy strategies for accelerating access to rural water and sanitation services," Water Science and Technology, vol. 63, no. 5, pp. 1037-1043, 2011.

[14] C. Anthonj, B. Diekkrüger, C. Borgemeister, and K. Thomas Kistemann, "Health risk perceptions and local knowledge of water-related infectious disease exposure among Kenyan wetland communities," International Journal of Hygiene and Environmental Health, vol. 222, no. 1, pp. 34-48, 2019.

[15] B. Gebremariam, G. Hagos, and M. Abay, "Assessment of community led total sanitation and hygiene approach on improvement of latrine utilization in Laelay Maichew District, North Ethiopia. A comparative cross-sectional study," PLoS One, vol. 13, no. 9, Article ID e0203458, 2018. 